\title{
Dispersal of Dioon edule cycad seeds by rodents in a tropical oak forest in Mexico
}

\author{
Laura Yáñez-Espinosa ${ }^{1,2 *}$, Felipe Barragán-Torres ${ }^{3}$, Alejandra Berenice Ibarra ${ }^{2}$ and \\ Jaime Iván Morales ${ }^{2}$ \\ ${ }^{1}$ Instituto de Investigación de Zonas Desèrticas, Universidad Autónoma de San Luis Potosí; \\ ${ }^{2}$ Programa Multidisciplinario de Posgrado en Ciencias Ambientales, Universidad Autónoma de \\ San Luis Potosí; ${ }^{3}$ CONACYT-IPICYT, División de Ciencias Ambientales, San Luis Potosí, México
}

Received for publication: 15 October 2021; Accepted for publication: 26 November 2021.

\begin{abstract}
Predation of seeds of the cycad Dioon edule by mice has been previously documented, demonstrating that the seeds' toxins are not harmful when combined with a varied diet. However, there is scarce evidence that they are a seed disperser. In a tropical oak forest in San Luis Potosí, Mexico, we experimented with seeds of $D$. edule and Quercus polymorpha, evaluating predators' preference and recording it with phototrapping. Burrows were sampled in concentric circles around a $D$. edule mother plant, and the types of burrows and condition of the seeds inside were identified with a borescope without destroying the burrows. The structure and composition of the forest were evaluated. The primary dispersion of $D$. edule seeds is by barochory. The rodents predate on seeds and prefer $Q$. polymorpha over D. edule (survival: $48.9 \%$ and $78.5 \%$, respectively). There are more escape and multiple burrows at 3-6 $\mathrm{m}$ with mature oaks. Rodents forget or abandon $D$. edule seeds in the burrows, and such seeds germinate at 3-6 m. Peromyscus leucopus is a short-distance secondary disperser and predator of $D$. edule seeds.
\end{abstract}

Key words: Seeds; burrows; forest; short distance; germination; density; barochory; zoochory.

\section{Introduction}

Cycads are a group of plants very ancient in origin (280 Myr) that were abundant and diverse during the Mesozoic era (225-65 Myr), known as the era of dinosaurs and cycads. Dinosaurs were the main dispersers of their seeds (zoochory) when herbivorous dinosaurs (sauropods and stegosaurs) consumed seed cones as a source of nutrients (Mustoe 2007; Butler et al. 2009). These plants declined after the disappearance of the dinosaurs, but small mammals such as marsupials (opossums) and placentals (rodents) likely replaced them (Mustoe 2007).

Dispersal of cycads by modern fauna has been discussed extensively (Norstog and

\footnotetext{
*Corresponding author. E-mail: lyaneze@uaslp.mx

${ }^{\circ}$ Copyright: the Author(s), 2021 | Licensee PAGEPress, Italy
} 
Nicholls 1997; Snow and Walter 2007; Hall and Walter 2013). Animals such as bears, peccaries and rodents act as dispersers, and it is even common to find gnawed seeds in burrows and on rocky ledges (zoochory) (Jones 1993; Schupp et al. 2010). However, due to the plants' intrinsic characteristics, they are also thought to disperse by barochory. The cycad cone disintegrates at maturity, and the megasporophylls release the seeds which, due to their large size $(1-3 \mathrm{~cm})$, fall to the ground by gravity and remain close to the mother plant. They could also be dispersed periodically by the drag of rainwater (ombrohydrochory) and scattered during the journey to lower areas with the help of streams that carry them to more distant sites (Van der Pijl 1982).

The cycad Dioon edule Lindl. is currently distributed in Mexico, and according to IUCN Red List its global conservation status is regarded as Near Threatened (NT) (Chemnick and Gregory 2010). It is distributed in the Huasteca region of San Luis Potosí, where it is relevant to people, cattle, and wildlife because the seeds are consumed as food, mainly during the dry season, although they are known to contain toxins that sometimes cause partial paralysis and even death in cattle (Yáñez-Espinosa 2009; Rubio-Méndez et al. 2021).

The $D$. edule seeds contain $22 \%$ proteins, $22 \%$ lipids, and $4 \%$ carbohydrates, making them suitable for consumption (Carranza- Alvarez and Carrillo-Inungaray 2017), considering that some studies have shown that dietary protein requirements for maintenance of adult mammals range from $19-25 \%$ for carnivores, $11-20 \%$ for omnivores and 5.5-9\% for wild ruminants, as well as carbohydrates range from $20-40 \%$ for carnivores, $70-80 \%$ for omnivores and 45-46\% for wild ruminants (Erlenbach et al. 2014; Roosendaal 2014; Felton et al. 2016). However, they also contain hydrolysable tannins, free amino acids, and alkaloids responsible for nervous system deterioration, digestive system organ problems, and possibly death, in $20 \%$ of the sarcotesta (fleshy seed coat) and $80 \%$ of the gametophyte (tissue surrounding the embryo) (Covarrubias 2009). In a previous laboratory study, individuals of the Mexican mouse Peromyscus mexicanus (Saussure, 1860) were subjected to forced starvation and an exclusive diet of $D$. edule seeds, resulting in nervous system affection and causing their death after seven days; however, with occasional consumption and a varied diet, they can consume the seeds without evident problems (González-Christen 1990).

Previous studies uncovered interactions between $D$. edule seeds and $P$. mexicanus (González-Christen 1990; Vovides 1990; Pavón-Saure 1999), identifying this species as a predator or secondary disperser (Norstog and Nicholls 1997). We have observed D. edule seeds removed no more than $5 \mathrm{~m}$ from the plant's base and directed towards rodent burrows in the field. A previous study showed that $97 \%$ of the seeds of the cycad Macrozamia miquelii (F. Muell.) A.DC. are removed from the plant's base to 1 or 4-5 $\mathrm{m}$ at the farthest (Hall and Walter 2013).

Seed dispersal by rodents results from the storage, abandonment, or forgetfulness of excess and unconsumed seeds, called animal storage behavior. The conditions present in burrows that are advantageous to germination are higher humidity levels than those in the environment, partial shade, and soil rich in organic matter thanks to rodent excreta or food remains (López-Ovando 2002; Dellafiore Capiello 2008; Fung-McLeod 2011; Barrios et al. 2012; Mori et al. 2017).

In a previous study, we found several species of wildlife interacting with $D$. edule seeds in the Huasteca region in San Luis Potosi, Mexico, with a dominance of the rodent genera Peromyscus Gloger, 1841, Neotoma Say and Ord, 1825, and Liomys Merriam, 1902, which were removing seeds (unpublished data). These rodents are opportunistic, adapting their diet to the immediately available resources (Rojas-Rojas and Barboza-Rodríguez 2007). The hypotheses we addressed were that: a) small rodents predate on $D$. edule seeds even 
when seeds of other species are available; b) rodent food gathering and storage habits in burrows favor the dispersal of $D$. edule seeds away from the parent plant; and c) burrows used by rodents to store $D$. edule seeds are found in greater proportion near the mother plant and away from other tree species. In this way, we proposed to a) determine the rodents that remove $D$. edule seeds; b) analyze seed preference and seed removal by rodents, c) determine the presence and abundance of seeds stored in burrows, d) assess the condition of stored seeds, e) determine the distance at which the seeds are dispersed from the mother plant, and f) analyze the association of established burrows with the structure and composition of the vegetation.

\section{Materials and methods}

We conducted the study at Tamasopo, San Luis Potosí, 21 $55^{\prime} 21^{\prime \prime} \mathrm{N} 99^{\circ} 23^{\prime} 33^{\prime \prime} \mathrm{W}$, in the Huasteca region. The site has an area of $1243.99 \mathrm{~m}^{2}$, with tropical oak forest vegetation, divided by a road from a sugarcane plantation plot (Figure 1). The soil is a mixture of rendzina, which is a shallow soil with an upper horizon up to $50 \mathrm{~cm}$ deep, rich in organic matter, and lithosol, which is a thinner soil, with a depth of fewer than $10 \mathrm{~cm}$ to its surface horizon. The substrate is sedimentary with outcrops of limestone rocks and, to a lesser extent, shale. The climate is semi-warm $\left(18-26^{\circ} \mathrm{C}\right)$ and humid with abundant rainfall in summer (2000 mm per year). The dry season lasts eight months (November-May), with less than $40 \mathrm{~mm}$ of precipitation in the driest month (Instituto Nacional de Estadística Geografía e Informática 2009).

We chose this site because we were previously able to identify rodent interactions with D. edule seeds. Likewise, due to the characteristics of the sites, we considered that rodents' food resource availability decreases in the dry season, so rodents will forage and collect available seeds to take to their burrows due to food shortage. By the end of the season,

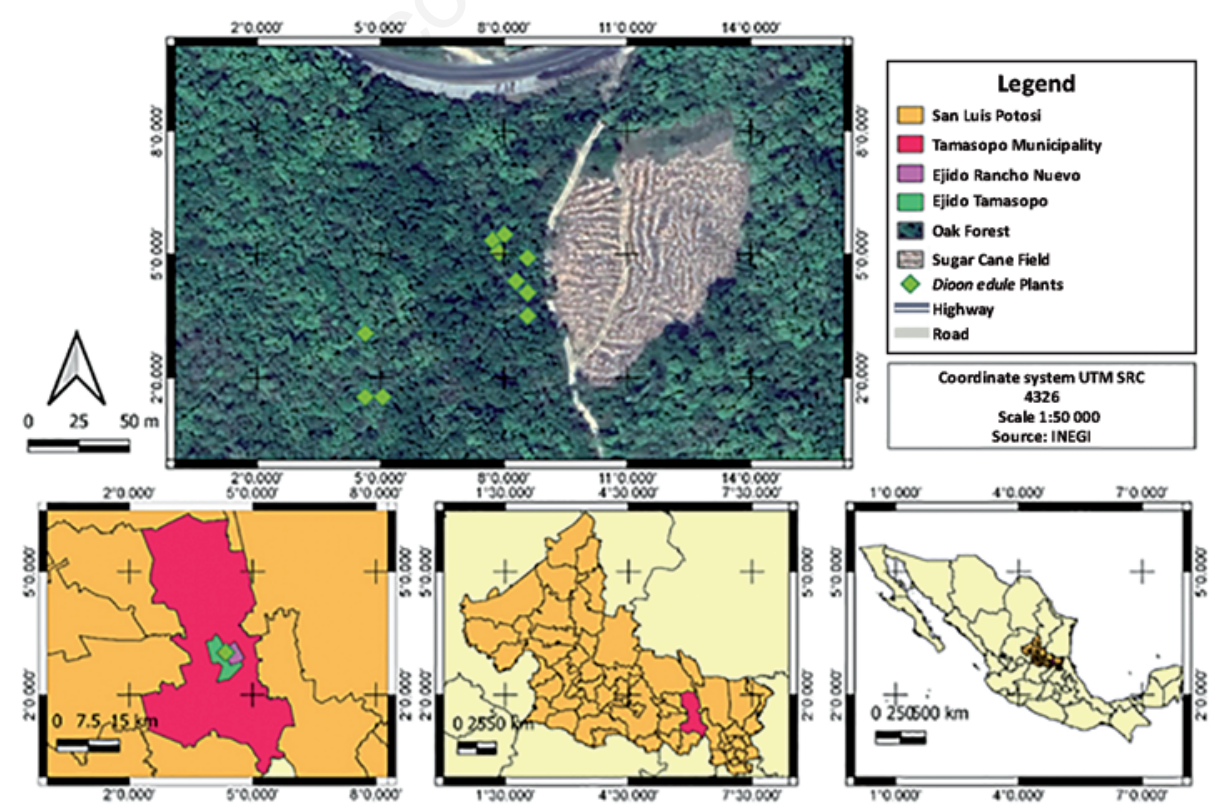

Figure 1. Study area location in Tamasopo, San Luis Potosí, Mexico. 
most of the seeds stored in the burrows will be predated, and the remaining seeds are more likely to survive and become established, favoring the plant's population growth.

\section{Seed dispersion (photo-trapping)}

In the first half of June 2017, we set nine bait stations using 30 seeds per station as bait and placed them on the ground: 15 D. edule and 15 Quercus polymorpha Schltdl. and Cham. The average seed size of $Q$. polymorpha is $1.38 \mathrm{~g}$ (González-Salvatierra et al. 2013), and that of $D$. edule is $4.14 \mathrm{~g}$ (Mora et al. 2013). All seeds used were collected locally and used exclusively in the photo-trapping $(n=270)$.

Each station was $50 \mathrm{~m}$ away from the next in a north-south orientation, starting at the first plant of $D$. edule in the map (Figure 1). Photo-trapping was carried out with nine camera traps (Cuddeback E3) with a 20-megapixel resolution, 0.25-s reaction speed, and 15.24 $\mathrm{m}$ detection range with a $5 \mathrm{~s}$ interval program. All cameras were maintained for 10 days, by quantifying daily in the morning (600 hours) and evening (1800 hours), removing seeds, and revising the camera traps.

Data from photographs were subsequently analyzed (camera trap number, date, time, species, habit diurnal or nocturnal, number of seeds, and foraging behavior). To discern if a sighting was of the same individual or a different one of the same species, the series of photos and the time between each shot was observed, and after $10 \mathrm{~min}$ they were assessed as different individuals. We used the criteria of Acevedo-Quintero and Zamora (2016) to classify foraging behavior: search (sniffing, touching, and attention), predation (ingestion of sarcotesta and seeds or only seeds), and removal (moving seeds out of the station).

\section{Seed dispersion}

Since we did not mark the seeds for tracking purposes in the photo-trapping experiment, we sampled the burrows in the first half of June 2018. We made an inventory of the mature female plants of $D$. edule and geo-referenced them with a GPS to locate them on the map. Then we selected 11 plants far enough away from each other so as not to overlap the sites and marked around each plant two concentric circles of radii 0-3 $\mathrm{m}$ and 3-6 $\mathrm{m}$ with a length meter, based on the dispersers studied scale (mice). Larger mammals remove seeds at greater distances and small mammals, such as mice, from 2 to $10 \mathrm{~m}$ maximum, with a greater concentration at distances of 2-5 m (Burbidge and Whelan 1982; Gonzalez-Christen 1990; Fung-Mcleod 2011; Sidhu and Datta 2015).

\section{Burrows distribution}

We defined the burrow as a cavity wider than $5 \mathrm{~cm}$ in diameter and more than $1.5 \mathrm{~m}$ in length and classified it as active based on the presence of abundant fur and food residues inside and food residues with loose soil at the entrance. Additionally, we measured the diameter at breast height (DBH) $1.3 \mathrm{~m}$ above the ground of the trees present in the concentric circles for analysis. The diameter classes were determined using the method of Bongers et al. (1988).

A census of burrows on the sites resulted in 176 burrows within the sites, 91 in the circle of radius $0-3 \mathrm{~m}$ and 85 in the circle of radius 3-6 m. Considering no difference between the number of burrows and the minimum number of burrows in one site, we randomly selected four in each concentric circle for analysis $(n=88)$. Each burrow was numbered and flagged to avoid repetition.

The analysis was performed by introducing a borescope without destroying the burrow. 
This instrument uses an optical system of lenses to transmit an image from the inspection area to the user and a fiber bundle to illuminate the object, with an analysis limit of $2.5 \mathrm{~m}$ in length, following the burrows' natural shape and direction. To classify burrows, we used the criteria of Harper and Batzli (1996), considering four types of burrows: a) duck hole, a small tunnel that acts as a temporary shelter; b) escape, a large tunnel for shelter and storage; c) single-nest, formed by several tunnels, a chamber and a nest, used for resting and storage; and d) multiple-nest, formed with more complex systems than the simple ones with the same use, and as a den for the young.

We classified the seeds found in the burrows as a) germinated, with the first leaf emerging; b) abandoned, with and without sarcotesta and without perforations; c) predated, with perforated sclerotesta and a damaged gametophyte; and d) dead, with damage in the sclerotesta caused by fungi and hollow or just hollow.

\section{Statistical analysis}

Dioon edule seeds and Quercus polymorpha acorn removal data were analyzed by estimating the survival function with the Kaplan-Meier method and the log-rank test to determine significant differences between the survival of each species. All burrow and seed data set analyses were performed with the Kruskal-Wallis nonparametric test to compare $\mathrm{k}$ independent samples and evaluate differences between sites and between concentric circle radii for burrow and seed frequency and type and tree diameter classes. Subsequently, we applied Dunn's multiple comparison test for each pair of groups to adjust the degree of significance (p) by Bonferroni correction. Spearman's correlation coefficient was also applied to evaluate the association between the variables burrow frequency, burrow type, and tree diameter class. All analyses were performed with XLSTAT v. 2021.1 software (Addinsoft, France).

\section{Results}

\section{Seed predation}

There were 18 sightings of Peromyscus leucopus (Figure 2a), three of Chaetodipus sp. (Figure 2b), one of Cuniculus paca (Linnaeus, 1766) (Figure 2c), and one of Sciurus aureogaster (F. Cuvier, 1829) (Figure 2d). Cuniculus, Peromyscus and Chaetodipus were observed at night standing, sitting, or lying down holding the seeds in their hands, either consuming them whole or consuming only the sarcotesta of D. edule. Likewise, Peromyscus removed one seed at a time due to its large size, making up to six trips in one night. Chaetodipus only removed acorns, although it predates the sarcotesta of $D$. edule. Sciurus descended to the ground to consume the seeds and remove a few during the day.

The foraging behavior consisted of Cuniculus and Sciurus predation of D. edule and Q. polymorpha whole seeds (4.76\%) and Peromyscus searching (4.76\%) the stations. However, Peromyscus and Chaetodipus predated on D. edule seeds sarcotesta at the stations (13.3\%) and, along with Sciurus, removed seeds of both species (90.47\%).

The survival function showed that $78.5 \%$ of $D$. edule and $48.9 \%$ of $Q$. polymorpha seeds remained on the stations after 10 days (Figure 3), and the log-rank test confirmed the highly significant difference between survival functions $(\mathrm{p}<0.001)$. The mean survival times of $D$. edule and $Q$. polymorpha seeds were 7.11 days \pm 0.18 and 6.27 days \pm 0.27 , respectively.

The seeds predated on at the site were $7.5 \%$ D. edule and $0.7 \% Q$. polymorpha, and those removed from the stations were $14.0 \% \mathrm{D}$. edule and $50.4 \%$ Q polymorpha. 

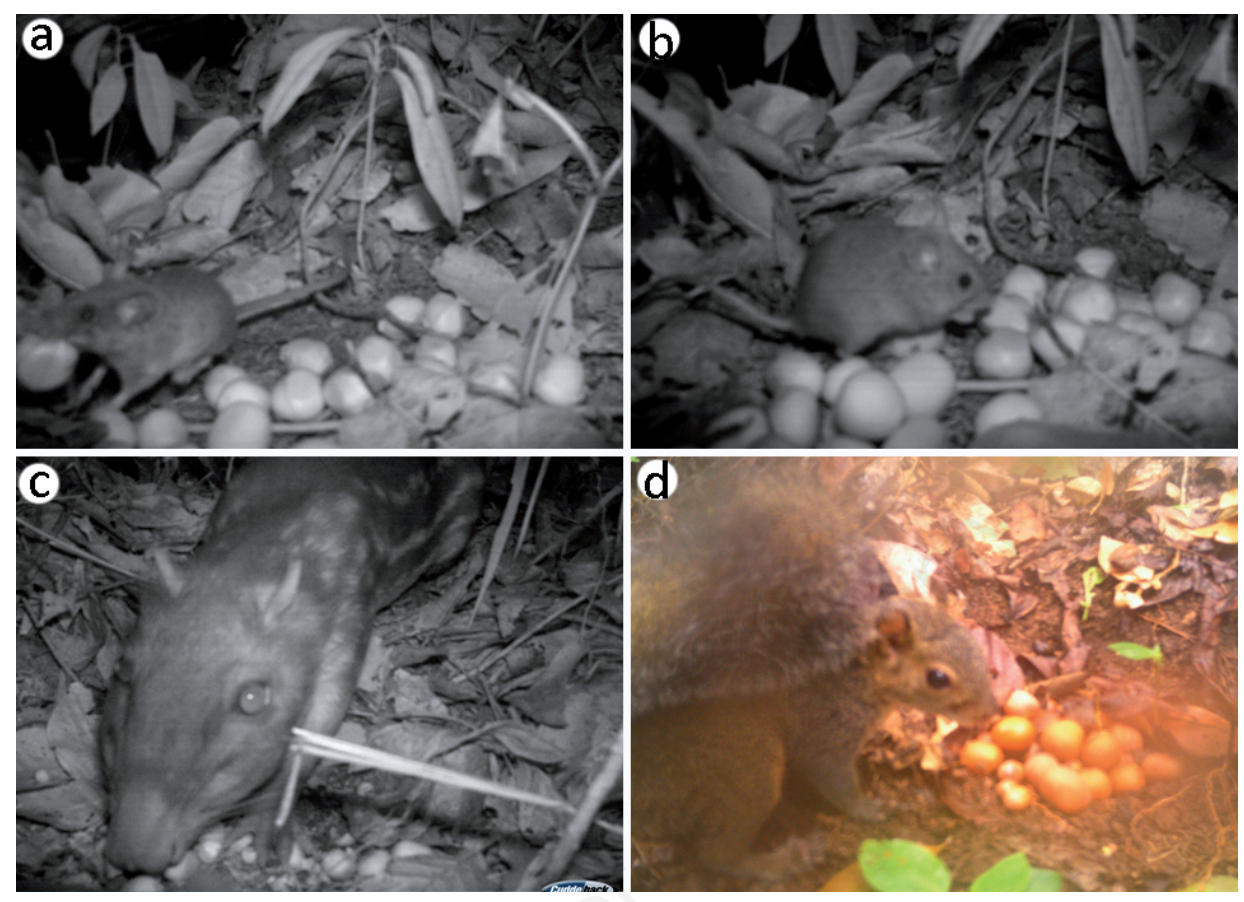

Figure 2. a) Peromyscus leucopus removing a seed of D. edule; b) Chaetodipus sp. consuming D. edule seed sarcotesta; c) Cuniculus paca; and d) Sciurus aureogaster at the stations with baits placed at Tamasopo, San Luis Potosí, Mexico.

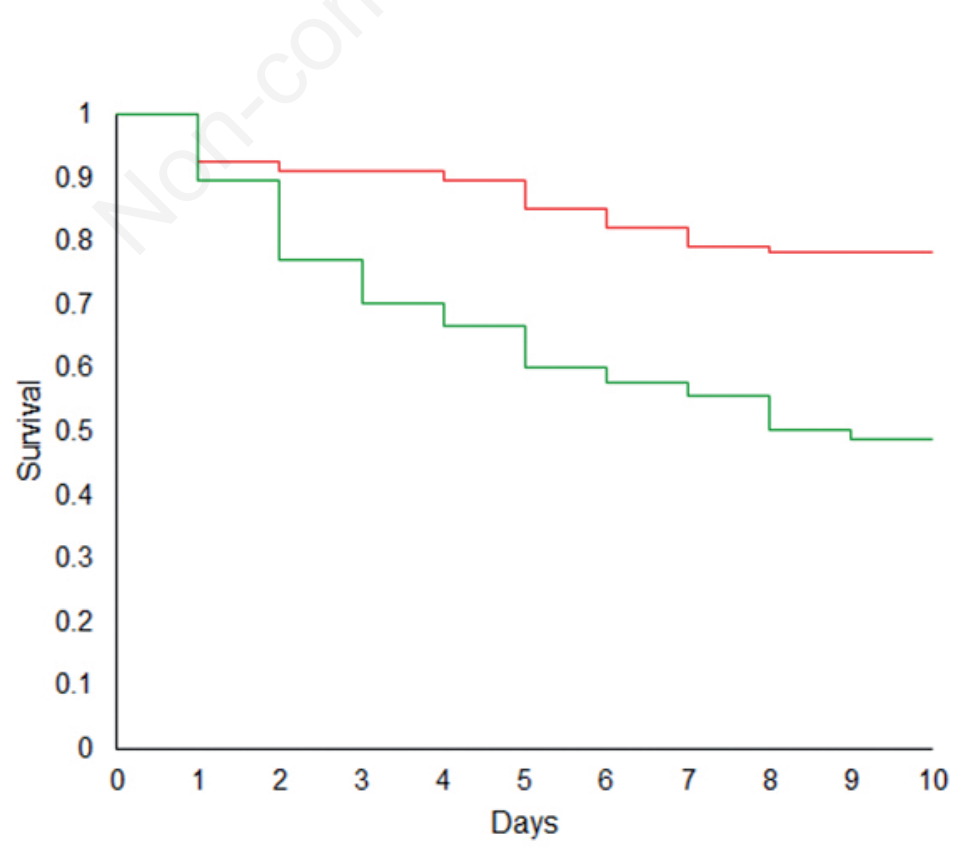

Figure 3. Cumulative survival function of $D$. edule seeds (red) and $Q$. polymorpha acorns (green). 


\section{Seed dispersion}

The oldest $D$. edule plants were scarce and scattered on the upper slope at $710 \mathrm{~m}$ a.s.1., while downslope, the highest proportion of young plants were found at $703 \mathrm{~m}$ a.s.1.

Burrows were frequent at the location, numbering an average of $15 \pm 0.42$ burrows site $^{-1}$; this means that there was one burrow every $7.36 \mathrm{~m}^{-2}$. The Kruskal-Wallis test showed statistically significant differences among the types of burrows present $(\mathrm{n}=88, \mathrm{df}=3, \mathrm{~K}=7.815$, $\mathrm{p}<0.01)$. The most frequent burrow type present at the location was the duck hole, and the least frequent was the multiple-nest burrow (Figure 4a). No significant differences were found between the $0-3 \mathrm{~m}$ and 3-6 $\mathrm{m}$ radii frequency of burrows for each type $(n=22, d f=1$, $\mathrm{K}=3.841, \mathrm{p}>0.05)$.

The maximum number of seeds per burrow was two, but there were only Quercus sp. or D. edule seeds in $25 \%$ burrows. There were no significant differences in the frequency of seeds among sites $(n=68, d f=10, K=6.05, p>0.05)$, or between radii $(n=22, d f=1$, $\mathrm{K}=18.31, \mathrm{p}>0.05$ ). Although there were differences in total seed frequency by species: 22 of D. edule and four Quercus $(\mathrm{n}=68, \mathrm{df}=1, \mathrm{~K}=5.99, \mathrm{p}<0.0001)$, no significant differences were detected among sites $(n=68, d f=10, K=8.43, p>0.05)$ (Figure $4 b)$. Most seeds were in duck holes and escape burrows, followed by single-nest and multiple-nest.

The highest proportion of $D$. edule seeds were predated (33.6\%) (Figure 5a), dead (29.5\%), or abandoned (25.3\%) (Figure $5 \mathrm{~b}$ ). Only $12.6 \%$ of $D$. edule seeds germinated
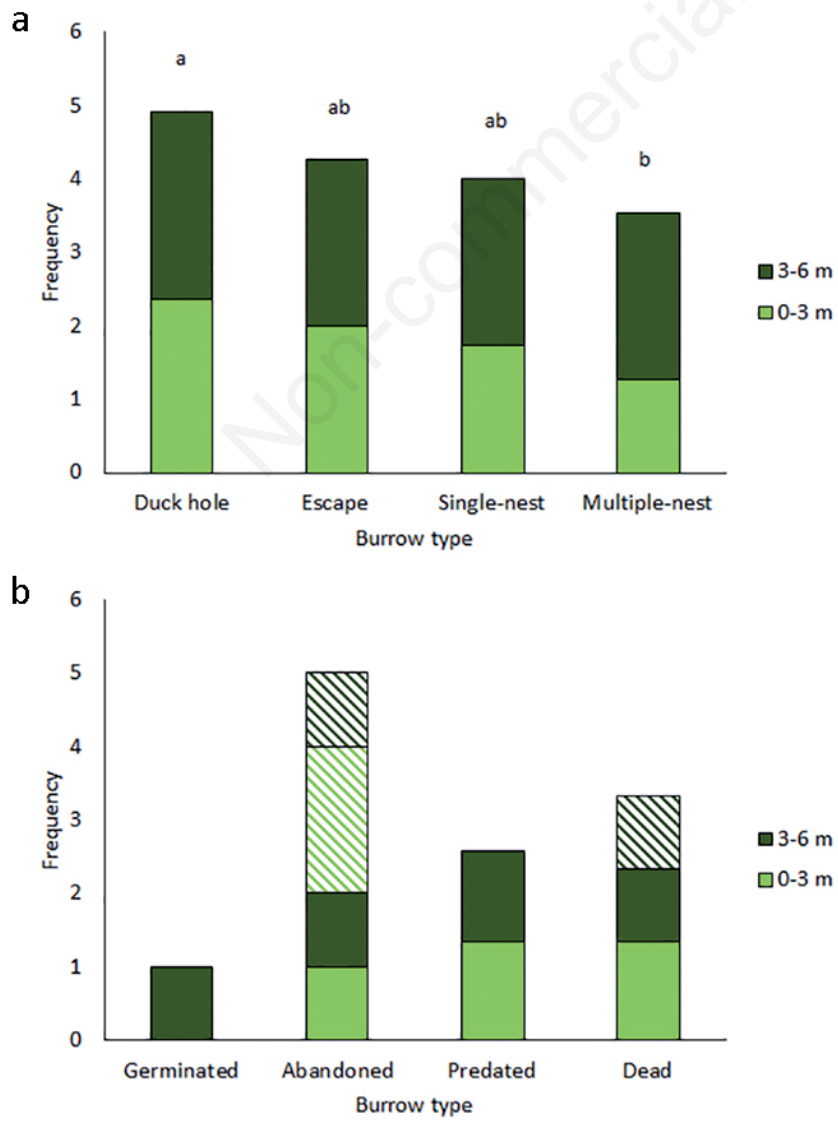

Figure 4. Kruskal-Wallis test for a) burrow type frequency in concentric circles from the

घ3-6 $\mathrm{m}$ chamal plant (D. edule); b) fre口0-3 $\mathrm{m}$ quency of seeds by species according to their condition type in concentric circles from $D$. edule plant (full = chamal; hatch $=$ oak). Different letters mean significant differences (Dunn's test $\mathrm{p}<0.05$ ). 
(Figure 5c) in multiple and escape burrows within 3-6 $\mathrm{m}$ of the mother plant, dispersed at short distances. There were no significant differences between $D$. edule seeds and acorns of different types $(\mathrm{n}=26, \mathrm{df}=5, \mathrm{~K}=11.07, \mathrm{p}>0.05)$.

\section{Burrows distribution}

The site's vegetation is an oak forest with tropical semi-deciduous forest elements and richness of 21 tree species (Table 1). The most frequent species were black oak (Quercus

Table 1. Species located in the sites at the oak forest in Tamasopo, San Luis Potosi, Mexico.

\begin{tabular}{lll}
\hline Acronym & Scientific name & Family \\
$\mathrm{Bd}$ & Brahea dulcis $($ Kunth) Mart. & Arecaceae \\
\hline $\mathrm{Bs}$ & Bursera simaruba (L.) Sarg. & Burseraceae \\
\hline $\mathrm{Cc}$ & Cercis canadensis $\mathrm{L}$. & Fabaceae \\
\hline $\mathrm{De}$ & Dioon edule Lindl. & Zamiaceae \\
\hline $\mathrm{Ae}$ & Ardisia escallonioides Schltdl. \& Cham. & Primulaceae \\
\hline $\mathrm{Jc}$ & Jatropha curcas L. & Euphorbiaceae \\
\hline $\mathrm{Ml}$ & Mimosa leucaenoides Benth. & Fabaceae \\
\hline $\mathrm{Mc}$ & Morus celtidifolia Kunth & Moraceae \\
\hline $\mathrm{Pl}$ & Persea liebmannii Mez & Lauraceae \\
\hline $\mathrm{Pc}$ & Protium copal (Schltdl. and Cham.) Engl. & Burseraceae \\
\hline $\mathrm{Qg}$ & Quercus germana Schltdl. and Cham. & Fagaceae \\
\hline $\mathrm{Qp}$ & Quercus polymorpha Schltdl. and Cham. & Fagaceae \\
\hline $\mathrm{Qx}$ & Quercus xalapensis Bonpl. & Fagaceae \\
\hline $\mathrm{Tr}$ & Tabebuia rosea (Bertol.) Bertero ex A.DC. & Bignoniaceae \\
\hline $\mathrm{Ta}$ & Tabernaemontana alba Mill. & Apocynaceae \\
\hline $\mathrm{Zg}$ & Zuelania guidonia (Sw.) Britton and Millsp. & Salicaceae \\
\hline
\end{tabular}
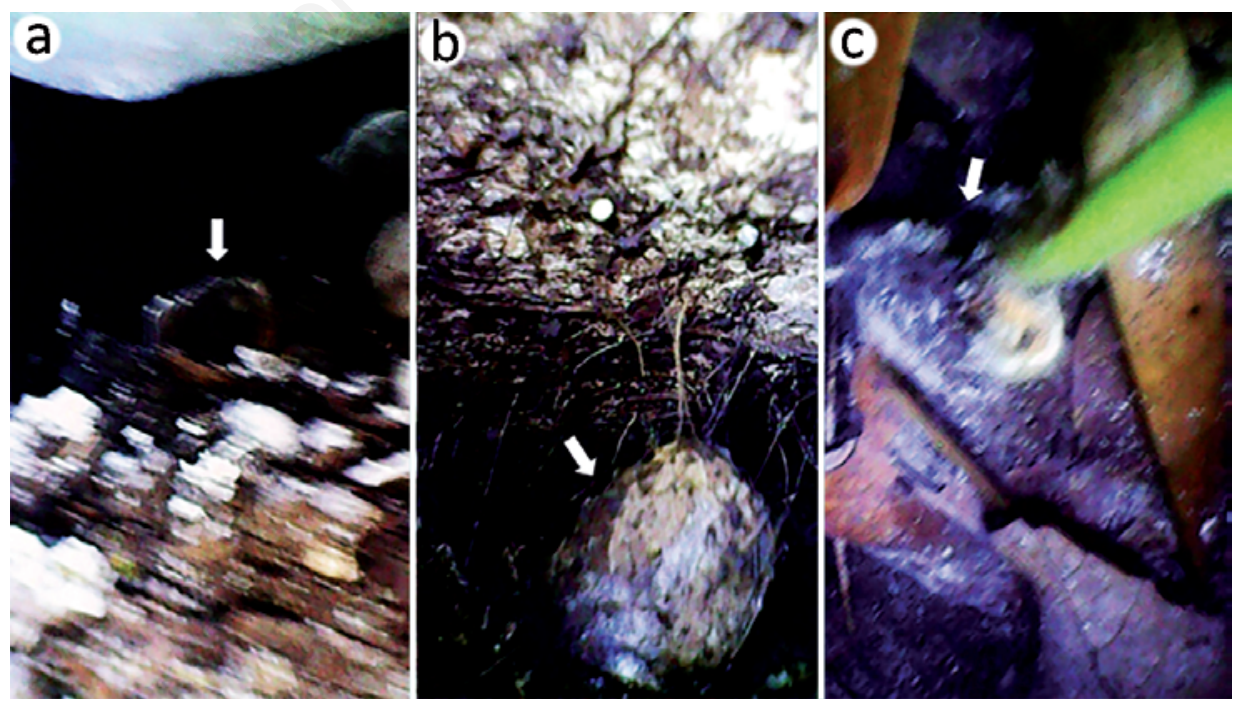

Figure 5. Types of seeds (arrow) in the burrows. a) predated; b) abandoned; c) germinated. 
polymorpha) and red oak (Quercus xalapensis), chamal (Dioon edule), and cojón de gato (Tabernaemontana alba) (Figure 6a). Black oak and red oak trees predominated with an abundance of three trees per $10 \mathrm{~m}^{2}$, followed by cow's foot (Cercis canadensis) and horse bone (Protium copal) with one tree and with a lower abundance of holm oak (Quercus germana), gumbo-limbo (Bursera simaruba), red avocado (Persea liebmannii), kite kite (Zuelania guidonia), and rosewood (Tabebuia rosea). In the lower stratum, chamal (Dioon edule) and cojón de gato (Tabernaemontana alba) predominated with two trees and mountain blackberry (Morus celtidifolia) and mad palm (Brahea dulcis) with less than 10 plants.

Significant differences existed in tree frequency between radii 0-3 $\mathrm{m}(41.05 \%)$ and 3$6 \mathrm{~m}(51.94 \%)(\mathrm{n}=88, \mathrm{df}=1, \mathrm{~K}=5.00, \mathrm{p}<0.05)$. There were significant differences among tree diameter classes for both radii $(\mathrm{n}=88, \mathrm{df}=7, \mathrm{~K}=33.91, \mathrm{p}<0.0001)$. Of the trees, $82.5 \%$ were small $(<23 \mathrm{~cm} \mathrm{DBH})$ and were within the $0-3 \mathrm{~m}$ radius, but there were more large trees (24-47 cm DBH) within the 3-6 m radius (Fig. 6b).

Although there was no difference in the number of burrows concerning distance from the plant, there was a slight tendency for a more significant presence of escape and multiple burrows in the 3-6 m radius from the mother plant, where the number of trees was double that in the $0-3 \mathrm{~m}$ radius, mainly oaks. There was no significant correlation between tree diameter and the frequency of trees, burrows, or type $(\mathrm{p}>0.05)$. However, the frequency of trees and multiple-nest burrows was positive and highly associated $(\rho=0.664, p<0.001)$.
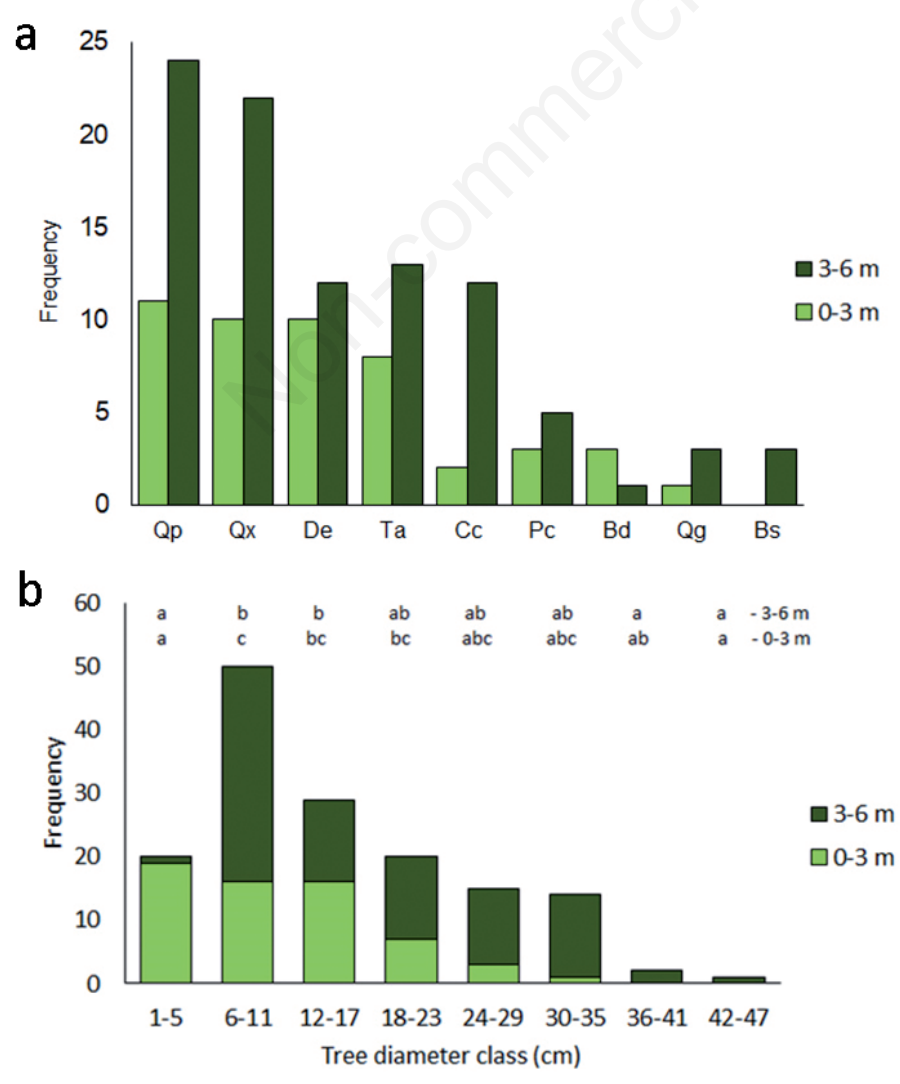

Figure 6. a) Tree species frequency located in concentric circles; b) KruskalWallis test for the diameter frequency distribution of trees located in concentric circles. Different letters mean significant differences (Dunn's test $\mathrm{p}<0.05)$. 


\section{Discussion}

\section{Seed predation}

It is relevant that there are at least four rodent species that predate on $D$. edule seeds when acorns are available, and not only small rodents as previously thought. The rodents Cuniculus paca, Sciurus aureogaster, Peromyscus leucopus, and Chaetodipus sp. found at the oak forest in Tamasopo are widespread, maintaining viable populations in small fragments of forest surrounded by crop land as in the study area (Navarrete-Gutiérrez et al. 1996; Núñez-Garduño 2005; Rojas-Rojas and Barboza-Rodríguez 2007; RodríguezMacedo et al. 2014; Martínez-Ceceñas et al. 2020). As opportunistic species, they predate on $D$. edule seeds despite the toxin content, adapting their diet to the available resources.

The rodents' attitude is calm while foraging during the day or at night, which would indicate that few natural predators could restrict foraging activity. However, there was a daytime sighting of the generalist felid Leopardus wiedii (Schinz, 1821), which includes both Peromyscus and Sciurus in its diet (Cinta-Magallón et al. 2012).

Foraging behavior showed that the main activity is seed removal, primarily by Peromyscus leucopus and Chaetodipus sp., and seed predation by the four rodent species. All rodents are predators of both species' seeds, confirming Peromyscus as found in previous studies (González-Christen 1990; Vovides 1990; Pavón-Saure 1999).

The four opportunistic predators should allocate the same foraging effort on both species' seeds, since each station had the same number (Valdovinos et al. 2010). The seeds of $D$. edule are large and have a sarcotesta, making them more profitable than smaller acorns of Q. polymorpha. We would expect predators to dedicate a higher foraging effort (Valdovinos et al. 2010), as occurred with Cuniculus paca at a 2:1 ratio of D. edule over Q. polymorpha. However, the foraging effort of Sciurus was 1:6, that of Peromyscus 1:3 and that of Chaetodipus $1: 2$, even though the acorn number decreased faster. This foraging strategy for the seed of $D$. edule could be explained by the presence of toxins, although they predated on the sarcotesta at the site, and the harder sclerotesta, larger size, and weight, which could imply a lower benefit and higher cost (energy waste) of consuming it whole or moving it to the burrow.

The photographic evidence does not allow us to conclude that $C$. paca and $S$. aureogaster are dispersers since we do not know if they transport seeds to their burrows; this question is to be addressed in future research. The effectiveness and efficiency of dispersal by seed-consuming rodents will depend on the sites where they deposit the seeds and the probability of recruiting new individuals into the population (Campos and Velez 2015).

\section{Seed dispersion}

The $D$. edule female cone megasporophylls detach, releasing the seeds that fall next to the mother plant or the entire cones fall to the ground (Mora et al. 2013), so their primary method of dispersal is barochory. At the locality, few older (taller) D. edule plants are observed at the higher elevation and downslope the higher proportion of younger plants, suggesting that this method of dispersal is the most common as in most cycads, when seeds roll downslope, as individuals grow on ridges and slopes (Jones 1993) and establish themselves in sites not far from mother plants.

The similarity in the frequency of $D$. edule and Quercus seeds between radii would indicate that rodents move the seeds of both species to the burrows but prefer those of Quercus since, in their constant search for food, they select the species with the highest seed production and whose consumption does not involve any long-term risk, such as toxin production by the seeds of $D$. edule. The Mexican mouse (P. mexicanus) can maintain a diet 
based on $D$. edule seeds for up to seven days without becoming ill (González-Christen 1990), so it is plausible that the rodents consume the seeds in seasons when other food is scarce. Even though rodents remove seeds, transport them to burrows, and prefer to eat the sarcotesta of seeds, incisor damage to the sclerotesta, such as that caused by the spiny pocket mouse (Liomys sp.) on espadaña (Dioon merolae De Luca, Sabato and Vázq.Torres) seeds, has been observed (Lázaro-Zermeño et al. 2011).

Dioon edule seeds were found most frequently in escape and multiple-nest burrows. Most seeds are predated, and those remaining may be forgotten and abandoned. Some seeds die, but $14 \%$ germinate within 3-6 m of the mother plant, dispersed at a short distance. Seeds could be forgotten by rodents in the escape burrows when they flee from predators or other danger, and in multiple-nest burrows, because stored large seeds with a hard sclerotesta and toxins in their tissues could be forgotten or abandoned when they move to another chamber or nest (Harper and Batzli 1996; Mora et al. 2013). A previous study carried out in the rainforest showed that approximately $12 \%$ of the stored seeds germinated, indicating that seed removal could reduce the competition between conspecific plants during reproduction (Sidhu and Datta 2015).

Generally, rodents ingest smaller seeds in their entirety but only consume the sarcotesta of large seeds (Galindo-González 1998). Hence, there is a greater chance of D. edule seed germination in these conditions, since the percentage increases when the photosynthetic photon flux density is lower $\left(17 \mu \mathrm{mol} \mathrm{m} \mathrm{m}^{-2} \mathrm{~s}^{-1}\right)$ (Yáñez-Espinosa et al. 2014). It would not be unusual if they germinated inside the burrows and then emerged from these to establish themselves. It is also common to observe $D$. edule seedlings and juveniles near and outside the burrows, probably from seeds abandoned or lost along the way.

This study shows that the habits of collecting and storing seeds in the burrows of Peromyscus leucopus mice favor the dispersal of $D$. edule seeds within a short distance from the mother plant, and that a small proportion germinate after being left inside.

\section{Burrows distribution}

The high density of burrows in the sites (one every $7.36 \mathrm{~m}^{2}$ ) suggests interaction with rodents in seed dispersal. When we compare our results with those of the maguey rat Neotoma leucodon (Merriam, 1894) with one burrow every $139 \mathrm{~m}^{2}$ in prickly pear cactus vegetation, and every $1250 \mathrm{~m}^{2}$ in desert plains (Martínez-Caldera et al. 2015), as well as the Florida mouse Podomys floridanus (Chapman, 1889) with one burrow every $1163 \mathrm{~m}^{2}$ in a xeric oak hammock (DePue 2005), the difference could be explained by the greater abundance of vegetation and a nearby cultivated area, with more food in a smaller area. We do not discount the possibility that this difference may be due to the small size of the sampling area, so we suggest expanding it in further research.

The similarity in the frequency of burrows with radii between $0-3 \mathrm{~m}$ and 3-6 $\mathrm{m}$ suggests the lack of an association with the availability of seeds near the $D$. edule plant. They are distributed evenly since practically one burrow of each type was in each radius.

At the study site, most of the burrows were escape burrows. Duck holes and escape burrows are known to function as temporary shelters to escape predators (DomínguezCastellanos et al. 2009). There is probably great predatory activity in the zone, and the location is close to the road and highway, or some of these burrows will be larger burrows in the future (Harper and Batzli 1996). Single-nest burrows function as storage and temporary stay locations and can be considered an intermediate stage between escape and multiple burrows (Domínguez-Castellanos et al. 2009). The function of multiple-nest burrows is to store food, mainly seeds of different species throughout the year and other materials for 
the construction of nests and permanent shelters. They are commonly the scarcest burrow type because their construction requires the greatest burrowing effort (Domínguez-Castellanos et al. 2009).

Dioon edule plants establish themselves in half-shade clearings, so most of the trees in the $0-3 \mathrm{~m}$ radius are primarily small, and those in the 3-6 m radius are larger. The highest frequency of trees is found in the smaller diameter classes, indicating sound reproduction and continuous tree incorporation. Although there is no difference in the number of burrows concerning distance from the plant, there is a high association between multiple burrows and the number of trees, mainly oaks. Complex burrows, more appropriate for food storage and as a den for the young, are in places where there are more trees with seasonal food availability (Harper and Batzli 1996; Domínguez-Castellanos et al. 2009). Several studies confirm that acorns are the primary food source for mice (DePue 2005), and the black oak (Q. polymorpha) produces acorns from October to January, coinciding with the release of D. edule seeds (Marroquin-Flores 1997). Then, it was found that the burrows used by mice to store $D$. edule seeds are abundant in the site and evenly distributed, so there is no evidence of proximity to the mother plants.

Seed-consuming rodents play a key role in determining forest structure and diversity by acting on post-seed-dispersal processes as secondary seed dispersers and predators (Acevedo-Quintero and Zamora-Abrego 2016; Razafindratsima 2017).

\section{Conclusions}

In an oak forest with tropical semi-deciduous forest elements, Dioon edule seeds are dispersed primarily by barochory, like all cycads. Four rodent species, Cuniculus paca, Sciurus aureogaster, Peromyscus leucopus, and Chaetodipus sp., predate D. edule seeds, influencing their survival rate and survival time. At the end of 10 days, D. edule seeds survived at a 1.6-fold higher rate and $10 \%$ longer than those of $Q$. polymorpha, showing the foragers' preference for the latter. These opportunistic rodents exhibited different foraging behaviors. The medium-sized rodents exerted a greater foraging effort on larger and more profitable $D$. edule seeds, while the small rodents made less effort, probably due to toxins, the larger size, and harder sclerotesta than that of acorns. The rodents removed the seeds and stored them in burrows along with acorns. There are numerous burrows on the site, mainly escape burrows requiring less effort than complex ones. Most acorns and D. edule seeds are abandoned/forgotten in escape and multiple-nest burrows. Multiple-nest burrows are farther from the $D$. edule mother plant and highly associated with numerous trees, providing an abundant source of acorns stored in the chamber and some $D$. edule seeds. This study proved that Peromyscus leucopus is a predator and a short-distance secondary disperser of $D$. edule seeds. Up to 1 out of 10 seeds of $D$. edule inside the burrows germinates with favorable light, organic matter, and humidity conditions, possibly emerging and establishing itself as a juvenile plant. The borescope was a helpful tool for the non-destructive analysis of burrows without contaminating them with exterior materials. However, its limitation is that it becomes complicated to manipulate after $2.5 \mathrm{~m}$ in length, especially in complex burrows. We will continue developing the tool for future research.

\section{Acknowledgments}

We thank Fernando Barrios for assistance with field work and Aurora Valdez-Yáñez for improving the figures. 


\section{Conflict of interest}

The authors declare no potential conflict of interest.

\section{Authors' contributions}

LYE designed the study, performed the statistical analyses, and wrote the final draft of the manuscript. All the authors contributed to the study conception, material collection and analysis. All the authors commented on previous versions of the manuscript and approved the final manuscript.

\section{Funding}

The Universidad Autónoma de San Luis Potosí financed the research through the project C18-FAI-05-74.74 granted to LYE.

\section{References}

Acevedo-Quintero JF, Zamora-Abrego JG. 2016. Papel de los mamíferos en los procesos de dispersión y depredación de semillas de Mauritia flexuosa (Arecaceae) en la Amazonía colombiana. Revista de Biología Tropical. 64(1):5-15. https://doi.org/10.15517/rbt.v64i1.18157

Barrios D, Mancina CA, González-Torres L. 2012. Evidencias de dispersión de semillas de plantas nativas por Capromys pilorides (Rodentia: Capromyidae). Revista del Jardín Botánico Nacional, Universidad de La Habana. 32-33 (2011-2012):315-317. Available from http://www.jstor.org/stable/ 23725938/

Bongers F, Popma J, Meave del Castillo J, Carabias J. 1988. Structure and floristic composition of the lowland rain forest of Los Tuxtlas, Mexico. Vegetatio. 74:55-88. https://doi.org/10.1007/ BF00045614

Burbidge AH, Whelan R J. 1982. Seed dispersal in a cycad, Macrozamia riedlei. Australian Journal of Ecology. 7:63-67. https://doi.org/10.1111/j.1442-9993.1982.tb01300.x

Butler RJ, Barrett PM, Penn MG, Kenrick P. 2009. Testing coevolutionary hypotheses over geological timescales: interactions between Cretaceous dinosaurs and plants. Biological Journal of the Linnean Society. 100:1-15. https://doi.org/10.1111/j.1095-8312.2010.01401.x

Campos CM, Velez S. 2015. Almacenadores y frugívoros oportunistas: el papel de los mamíferos en la dispersión del algarrobo (Prosopis flexuosa DC) en el desierto del Monte, Argentina. Ecosistemas. 24(3):28-34. https://doi.org/10.7818/ECOS.2015.24-3.05

Carranza-Alvarez C, Carrillo-Inungaray ML. 2017. Perfil nutrimental de diferentes tejidos y frutos de la palma chamal (Dioon edule). Acta Universitaria. 27(2):3-9. https://doi.org/10.15174/au. 2017.1208

Chemnick J, Gregory T. 2010. Dioon edule Lindl. The IUCN Red List of Threatened Species. https://doi.org/10.2305/IUCN.UK.2010-3.RLTS.T42158A10643785.en

Cinta-Magallón CC, Bonilla-Ruz CR, Alarcón-D I, Arroyo-Cabrales J. 2012. Dos nuevos registros de margay (Leopardus wiedii) en Oaxaca, México, con datos sobre hábitos alimentarios. UNED Research Journal. 4(1):33-40. https://doi.org/10.22458/urj.v4i1.131

Covarrubias A. 2009. Caracterización de la locomoción de ratas expuestas a semillas de Dioon edule Lindl. BSc Thesis. Universidad Autónoma de San Luis Potosí, San Luis Potosí, México. $62 \mathrm{pp}$.

Dellafiore Capiello CM. 2008. Ecología del conejo silvestre (Oryctolagus cuniculus) en un sistema dunar costero. Ecosistemas. 17(2):103-105.

DePue JR. 2005. Responses of the Florida mouse (Podomys floridanus) to habitat management. MSc Thesis. University of Central Florida, USA. 67 pp.

Domínguez-Castellanos Y, Meza BH, Mendoza A, González GC. 2009. Madrigueras de Liomys 
pictus en dos selvas tropicales del Pacífico mexicano. Revista Mexicana de Mastozoología (Nueva Época). 13(1):63-81. https://doi.org/10.22201/ie.20074484e.2009.13.1.36

Erlenbach JA, Rode KD, Raubenheimer D, Robbins CT. 2014. Macronutrient optimization and energy maximization determine diets of brown bears. Journal of Mammalogy. 95(1):160-168. https://doi.org/10.1644/13-MAMM-A-161

Felton AM, Felton A, Raubenheimer D, Simpson SJ, Krizsan SJ, Hedwall PO, Stolter C. 2016. The nutritional balancing act of a large herbivore: An experiment with captive moose (Alces alces $\mathrm{L}$ ). PLoS One. 11(3):e0150870. https://doi.org/10.1371/journal.pone.0150870

Fung-McLeod EM. 2011. Dispersión de semillas por mamíferos terrestres en bosques latifoliados del Atlántico Norte de Nicaragua después del huracán Félix. Recursos Naturales y Ambiente. 62:37-46.

Galindo-González J. 1998. Dispersión de semillas por murciélagos: su importancia en la conservación y regeneración del bosque tropical. Acta Zoológica Mexicana (Nueva serie). 73:57-74. https://doi.org/10.21829/azm.1998.73731727

González-Christen A. 1990. Algunas interacciones entre Dioon edule (Zamiaceae) y Peromyscus mexicanus (Rodentia: Cricetidae). La Ciencia y el Hombre. 5:77-92.

González-Salvatierra C, Badano EI, Flores J, Rodas JP. 2013. Germinación, infestación y viabilidad en bellotas de Quercus polymorpha (Schltdl. and Cham.) tras un año de almacenamiento. Revista Chapingo. Serie Ciencias Forestales y del Ambiente. 19(3):351-362. https://doi.org/10.5154/r.rchscfa.2012.07.044

Hall JA, Walter GH. 2013. Seed dispersal of the Australian cycad Macrozamia miquelii (Zamiaceae): are cycads Megafauna-dispersed "grove forming" plants? American Journal of Botany. 100(6): 1127-1136. doi:https://doi.org/10.3732/ajb.1200115

Harper SJ, Batzli GO. 1996. Effects of predators on structure of the burrows of voles. Journal of Mammalogy. 77(4):1114-1121. https://doi.org/10.2307/1382793

Instituto Nacional de Estadística, Geografía e Informática. 2009. Prontuario de información geográfica municipal de los Estados Unidos Mexicanos. Tamasopo, San Luis Potosí. Clave geoestadística 24036.

Jones DL. 1993. Cycads of the world. Ancient plants in today's landscape. Washington, DC: Smithsonian Institution Press. 456 pp.

Lázaro-Zermeño JM, González-Espinosa M, Mendoza A, Martínez-Ramos M, Quintana-Ascencio PF. 2011. Individual growth, reproduction, and population dynamics of Dioon merolae (Zamiaceae) under different leaf collection histories in central Chiapas, Mexico. Forest Ecology and Management. 261:427-439. https://doi.org/10.1016/j.foreco.2010.10.028

López-Ovando A. 2002. Distribución y relaciones ecológicas del chamal (Dioon edule var. angustifolium) en la Sierra de San Carlos, Tamaulipas, Méx. MSc Thesis. Universidad Autónoma de Nuevo León, México. 70 pp.

Marroquin-Flores RA. 1997. Algunos aspectos sobre la fenologia, produccion de bellota y propagacion de seis especies de encino Quercus L. del estado de Nuevo León, México. MSc Thesis. Universidad Autónoma de Nuevo León, México. 147 pp.

Martínez-Caldera JM, Palacio-Núñez J, Clemente-Sánchez F, Martínez-Montoya JF, Sánchez-Rojas G, Olmos-Oropeza G. 2015. Distribución potencial de la rata magaueyera (Neotoma leucodon Merriam 1984) y densidad de madrigueras en el sur del desierto chihuahuense. Therya. 6(2):421-434. https://doi.org/10.12933/therya-15-223

Martínez-Ceceñas Y, Hénaut Y, Naranjo EJ, Carrillo-Reyes A. 2020. Conducta alimentaria del tepezcuintle (Cuniculus paca) en dos sitios con distinto uso del suelo en la selva Lacandona, Chiapas, México. Revista Mexicana de Biodiversidad. 91:e912971. http://dx.doi.org/10.22201/ib.20078706e. 2020.91.2971

Mora R, Yáñez-Espinosa L,Flores J, Nava-Zárate N. 2013. Strobilus and seed production of Dioon edule (Zamiaceae) in a population with low seedling density in San Luis Potosí, México. Tropical Conservation Science. 6:268-282. https://doi.org/10.1177/194008291300600208

Mori E., Mazza G., Galimberti A., Angiolini C., Bonari G. 2017. The porcupine as "Little Thumbling": the role of Hystrix cristata in the spread of Helianthus tuberosus. Biologia. 72:1211-1216.

Mustoe GE. 2007. Coevolution of cycads and dinosaurs. The Cycad Newsletter. 30(1):6-9. 
Navarrete-Gutiérrez DA, Alba-López MP, March-Mifsut IJ, Espinoza-Medinilla EE. 1996. Mamíferos de la Selva El Ocote, Chiapas. In: Vásquez-Sánchez MA, March-Mifsut IJ, editors. Conservación y desarrollo sustentable en la selva El Ocote, Chiapas. San Cristóbal de Las Casas, Chiapas, México: El Colegio de la Frontera Sur, Comisión Nacional para el Conocimiento y uso de la Biodiversidad, Centro de Estudios para la Conservación de los Recursos Naturales. p. 179-207.

Norstog KJ, Nicholls TJ. 1997. The Biology of the Cycads. Ithaca, New York: Cornell University Press. 363 pp.

Núñez-Garduño A. 2005. Los mamíferos silvestres de Michoacán: diversidad, biología e importancia. Morelia, Michoacán, México: Universidad Michoacana de San Nicolás de Hidalgo. 429 pp.

Pavón-Saure M. 1999. Germinación y sobrevivencia de plántulas de Dioon edule Lindley (Zamiaceae) en su hábitat natural cerro del Papayal-Achichuca, Municipio de Coatepec, Ver. BSc Thesis. Universidad Veracruzana, Veracruz, México. 37 pp.

Razafindratsima O. 2017. Post-dispersal seed removal by rodents in Ranomafana rain forest, Madagascar. Journal of Tropical Ecology. 3(3):232-236. https://doi.org/10.1017/S0266467417000104

Rodríguez-Macedo M, González-Christen A, León-Paniagua LS. 2014. Diversidad de los mamíferos silvestres de Misantla, Veracruz, México. Revista Mexicana de Biodiversidad. 85:262-275. https://doi.org/10.7550/rmb.36143

Rojas-Rojas L, Barboza-Rodríguez M. 2007. Ecología poblacional del ratón Peromyscus mexicanus (Rodentia: Muridae) en el Parque Nacional Volcán Poás, Costa Rica. Revista de Biología Tropical. 55(3-4):1037-1050.

Roosendal B. 2014. Wildlife nutrition and feeding. Spesfeed Consulting. https://spesfeed.com/ 2014/04/wildlife-nutrition-feeding/

Rubio-Méndez G, Prado A, Bede JC, De-Nova JA, Flores J, Reyes-Agüero JA, Yáñez-Espinosa L. 2021. The Endangered Species Dioon edule in the Sierra Madre Oriental in San Luis Potosí: Demography and Genetic Diversity. In: Hufnagel L, editor. Natural History and Ecology of Mexico and Central America. London: IntechOpen. p. 95-113.

Schupp EW, Jordano P, Gómez JM. 2010. Seed dispersal effectiveness revisited: a conceptual review. New Phytologist. 188(2):333-353. https://doi.org/10.1111/j.1469-8137.2010.03402.x

Sidhu S, Datta A. 2015. Tracking seed fates of tropical tree species: Evidence for seed caching in a tropical forest in North-East India. PLoS ONE. 10(8): e0134658. https://doi.org/10.1371/ journal.pone. 0134658

Snow EL, Walter GH. 2007. Large seeds, extinct vectors and contemporary ecology: Testing dispersal in a locally distributed cycad, Macrozamia lucida (Zamiaceae). Australian Journal of Botany. 55: 592-600. https://doi.org/10.1071/BT07009

Valdovinos FS, Urbani P, Ramos-Jiliberto R. 2010. Análisis de las consecuencias del comportamiento adaptativo individual sobre la estabilidad poblacional: El caso del forrajeo óptimo. Revista Chilena de Historia Natural. 83:207-218.

Van der Pijl L. 1982. Principles of dispersal in higher plants. Berlin, Heidelberg: Springer-Verlag. $214 \mathrm{pp}$.

Vovides AP. 1990. Spatial distribution, survival, and fecundity of Dioon edule (Zamiaceae) in a tropical deciduous forest in Veracruz, Mexico, with notes on its habitat. American Journal of Botany. 77:1532-1543. http://dx.doi.org/10.4067/S0716-078X2010000200001

Yáñez-Espinosa L. 2009. Chamal (Dioon edule Lindl.) in the State of San Luis Potosí, México. The Cycad Newsletter. 32:18-21.

Yáñez-Espinosa L, Flores J, Rodríguez-Millán PS, Rubio-Méndez G. 2014. Influence of germination date on Dioon edule (Zamiaceae) seedling tolerance to water stress. Journal of Plant Research. 127:413-422. http://dx.doi.org/10.1007/s10265-014-0624-4

This article is distributed under the terms of the Creative Commons Attribution Noncommercial License (by-nc 4.0) which permits any noncommercial use, distribution, and reproduction in any medium, provided the original author(s) and source are credited. 